\title{
Association between Arterial Stiffness and Acute Exacerbations in Patients with Chronic Obstructive Pulmonary Disease
}

\author{
Sinem Özyılmaz ${ }^{1}$ İsa Özyılmaz², Osman Akın Serdar ${ }^{1}$, Esra Uzaslan ${ }^{3}$ \\ ${ }^{1}$ Uludağ Üniversitesi Tıp Fakültesi, Kardiyoloji Anabilim Dalı, Bursa \\ ${ }^{2}$ Mehmet Akif Ersoy Göğüs Kalp Damar Cerrahisi Eğitim ve Araştırma Hastanesi, Çocuk Kardiyolojisi, İstanbul \\ ${ }^{3}$ Uludağ Üniversitesi Tıp Fakültesi, Göğüs Hastalıkları Anabilim Dalı, Bursa
}

\begin{abstract}
Objective: Acute exacerbation in chronic obstructive pulmonary disease (COPD) can result in a major systemic effect due to hypoxemia and systemic inflammation. In our study, we investigated the effects of acute exacerbation of COPD on arterial stiffness (AS) in patients admitted to our hospital.

Methods: Enrolled in the study were 21 healthy volunteers who constituted the control group and 25 patients who had been admitted to our hospital between May and December 2011 with acute exacerbation of COPD diagnosed based on Global Initiative for Chronic Obstructive Lung Disease Diagnosis and Treatment Guidelines.

Results: The average AS values were $1498.00 \pm 699.35$ dyne.sec.cm- 5 in patients with mild hypoxemia, 2095.09 \pm 883.31 dyne.sec.cm-5 in those with moderate hypoxemia, and 2077.66 \pm 99.15 dyne.sec. $\mathrm{cm}-5$ in those with severe hypoxemia. There was no statistically significant correlation between severity of hypoxemia and AS value ( $>0.05)$. But, there was a statistically significant difference in values of AS, compared between mild hypoxemia $\left(\mathrm{PaO}_{2} \geq 60 \mathrm{~mm} \mathrm{Hg}\right)$ and moderate and severe hypoxemia $\left(\mathrm{PaO}_{2}<60 \mathrm{~mm} \mathrm{Hg}\right)(\mathrm{p}=0.047)$. Arterial stiffness was significantly higher, while the large artery elasticity index (LAEI) and small artery elasticity index (SAEI) were lower in the patient group as compared to the control group $(p=0.002$, $\mathrm{p}=0.043$, and $\mathrm{p}=0.036$, respectively).
\end{abstract}

Conclusion: In $\mathrm{PaO}_{2}<60 \mathrm{mmHg}$ AS values were higher than in $\mathrm{PaO}_{2} \geq 60 \mathrm{mmHg}$ during acute exacerbation of COPD. The AS value was significantly higher while LAEI and SAEI were significantly lower in the patient group as compared to the control group.

Keywords: Arterial stiffness, exacerbation, chronic obstructive pulmonary disease

\section{Özet}

Amaç: Kronik obstrüktif akciğer hastalığı (KOAH) akut atağında hipoksemi, sistemik inflamasyon gibi nedenler ile birçok sistemik etkiler meydana gelmektedir. Bu çalışmada, KOAH akut atak ile hastaneye başvuran hastalarda akut atağın arteriyel sertlik üzerine etkileri araştırldl.

Yöntemler: Çalısmaya Uludağ Üniversitesi Göğüs Hastalıkları Kliniğine, Mayıs 2011 ile Aralık 2011 tarihleri arasında başvuran ve GOLD Tanı ve Tedavi Rehberi kriterlerine göre KOAH tanısı alan, KOAH akut ataklı 25 hasta ve 21 gönüllü olgu alındı.

Bulgular: Arteriyel sertlik değerleri hafif, orta ve ileri derecede hipoksemi olanlarda sirasiyla $1498.00 \pm 699.35$ dyne $/ \mathrm{sec} / \mathrm{cm}-5$, $2095.09 \pm 883.31 \mathrm{dyne} / \mathrm{sec} / \mathrm{cm}-5,2077.66 \pm 99.15 \mathrm{dyne} / \mathrm{sec} / \mathrm{cm}-5$ ölçüldü. Hipoksemi şiddeti ile arteriyel sertlik arasında istatistiksel anlamlı korelasyon saptanmadı $(\mathrm{p}>0.05)$. Fakat hafif hipoksemi $(\mathrm{PaO} 2 \geq 60 \mathrm{mmHg})$ ve orta, ileri hipoksemi $(\mathrm{PaO} 2<60 \mathrm{mmHg})$ değerleri arasında, AS değerlerine göre istatistiksel anlamlı fark saptandı $(\mathrm{p}=0.047)$. Hasta grubunda, sağllklı kontrol grubuna göre AS yüksek, büyük arter elastik indeksi, küçük arter elastik indeksi düşük saptandı ve istatistiksel olarak anlamlı bulundu ( $p=0.002, p=0.043$ ve $\mathrm{p}=0.036$, sirasiyla).

Sonuç: KOAH' in akut alevlenme döneminde $\mathrm{PaO} 2 \geq 60 \mathrm{mmHg}$ olduğu zaman ölçülen arteriyel sertlik değerlerine göre, $\mathrm{PaO} 2<60$ mmHg olduğu zaman ölçülen değerlerinin daha yüksek olduğu saptanmıştır. Kronik obstrüktif akciğer hastalığı olan akut ataktaki hastalarda sağlıklı kontrol grubuna göre AS değeri anlamlı yüksek, büyük arter elastik indeksi, küçük arter elastik indeksi anlamlı düşük saptanmiştır.

Anahtar Kelimeler: Arteriyel sertlik, akut alevlenme, kronik obstrüktif akciğer hastalı̆̆
Received Date / Alındığı Tarih: 08.08.2013 Accepted Date / Kabul Tarihi: 14.10.2013

Address for correspondence / Yazışma Adresi İsa Özyllmaz, Mehmet Akif Ersoy Göğüs Kalp Damar Cerrahisi Eğitim ve Araştırma Hastanesi, Çocuk Kardiyolojisi, İstanbul, Türkiye

E-mail / E-posta: isaozyilmaz@gmail.com

(C) Copyright 2014 Turkish Respiratory Society (TRS) Eurasian J Pulmonol 2014

DOI: $10.5152 /$ ejp.2014.24482

-Available online at www.eurasianjpulmonol.com

\section{INTRODUCTION}

Chronic obstructive pulmonary disease (COPD) is characterized by non-reversible airflow obstruction and recurrent acute exacerbation due to an abnormal chronic inflammatory response of the lungs to hazardous particles and gas (1). Recent studies have described extra-pulmonary findings in COPD (also referred to as the systemic effects of COPD), which have a prognostic effect on treatment, followup, and disease management $(2,3)$.

Coronary heart disease and stroke are factors that increase morbidity and mortality in patients with COPD. Arterial stiffness (AS) indicates decreased arterial elasticity and damage in the vessel wall. It is an independent determining factor for cardiovascular events and mortality in healthy individuals 
and a more reliable marker than classic cardiovascular risk factors $(4,5)$. Measuring pulse wave velocity (PWV) has shown that the AS rate tends to be higher in countries with high cardiovascular disease risk $(5,6)$. In one study, Hung et al. report that PWV measurements are important in detecting early atherosclerosis and can be used as a marker of long-term cardiovascular disease risk (4). Using PWV as a measure of AS is non-invasive, relatively inexpensive, and convenient and is also considered the most reliable qualitative test for detection of AS $(7,8)$. It has been shown that elastin fragmentation occurs in the connective tissue of patients with emphysematous lungs and AS. These studies confirm the link between pulmonary and vascular diseases and high cardiovascular mortality in COPD patients (5). Several studies have reported a relationship between AS and the severity of airflow obstruction in COPD patients, due to similar pathophysiological processes in pulmonary and vascular tissue $(6,9,10)$. The purpose of the present study was to investigate the effects of acute exacerbation of COPD on AS in patients admitted to our hospital.

\section{METHODS}

Enrolled in this study were 21 healthy volunteers who constituted the control group and 25 patients who had been admitted to the Pulmonary Disease Clinic of Uludağ University between May and December 2011 with acute exacerbation of COPD diagnosed based on Global Initiative for Chronic Obstructive Lung Disease Diagnosis and Treatment Guidelines criteria (11). The study was approved by the Uludağ University School of Medicine Medical Research Ethical Commission on June 28, 2011 (Decision \#2011-14/14). Excluded from the study were patients who had coronary artery disease diagnosed by coronary angiography, myocardial perfusion scintigraphy, and computed tomography and those who had diabetes mellitus or high blood pressure, consumed cigarettes during study and alcohol, or had been previously treated with antibiotics, steroids, or antihypertensive drugs. The patients had similar ages and genders to healthy control subjects. All study participants were required to sign an informed consent form, and those who did not were excluded from the study.

The patients were evaluated for COPD using anamnesis, physical examination, chest X-rays, and arterial blood gas (ABG) tests. Patients with exacerbation of COPD and high CRP levels were admitted to the hospital, where they underwent a spirometry test. Height and weight measurements of the patients and the controls were taken, and body mass indexes were calculated using the weight/height ${ }^{2}\left(\mathrm{~kg} / \mathrm{m}^{2}\right)$ formula. On the first day of admission, ABG measurements were made with a Stat Profile Critical Care Xpress blood gas analyzer (Nova Biomedical) within 30 minutes of drawing a 2-cc blood sample from the radial artery with a heparinized injector, after the patient had been breathing room air for at least 30 minutes. Hypoxemia classification was based on arterial oxygen pressure $\left(\mathrm{PaO}_{2}\right)$ levels. Arterial $\mathrm{PaO}_{2}$ of 60-80 $\mathrm{mm} \mathrm{Hg}$ was classified as mild hypoxemia, $40-59 \mathrm{~mm} \mathrm{Hg}$ was classified as moderate hypoxemia, and $>40 \mathrm{~mm} \mathrm{Hg}$ was classified as severe hypoxemia (12).

All evaluations of patients and controls were based on radial artery PWV, which was measured using the non-invasive Pulse Wave Sensor HDI system (Hypertension Diagnostics, Eagan, MN; Serial No: CR000344) (7). The system provides information about the AS of a running vessel. Arterial pulse is a fluctuation marker, resulting from cardiac contraction. The passage of blood from the left ventricle to the aorta forms flow, pressure, and diameter pulsation through the arterial tree. Pulse wave velocity is defined as the distance traveled by a pulse wave from one end of a vessel to the other, divided by the time that has passed (PWV = distance [m] / time [s]) (7). Measurements were taken after the patients and controls had rested in a supine position for 10 minutes, in a quiet daytime environment with a temperature of $22 \pm 1^{\circ} \mathrm{C}$. Care was taken to ensure that the patients did not drink coffee or smoke 2 hours prior to the procedure. A cuff of an appropriate length was wrapped to $2-3 \mathrm{~cm}$ over the point at which the brachial artery was palpated, and a sensor was placed over the radial artery $(8,13)$. The parameters obtained from these measurements were as follows: calculated stroke volume $(\mathrm{mL} /$ stroke), cardiac output (L/min), large artery elasticity index (LAEl; mL/mm Hgx10), small artery elasticity index (SAEl; mL/mm Hgx100), AS (dyne.sec.cm5), and total vascular impedance (TVl; dyne.sec.cm-5). Only AS values were used for the comparison of patients, based on hypoxemia levels. The LAEI (mL/mm Hgx10), SAEI (mL/mm Hgx100), AS (dyne.sec. $\mathrm{cm}-5$ ), and TVI (dyne.sec.cm-5) values were compared between the patient and control groups.

\section{Statistical Analyses}

The SPSS software package version 11.5 was used for statistical analysis of the obtained data. Kruskal-Wallis test was used for comparison of quantitative data, descriptive statistical methods, and parameters of normal distribution between groups. The Mann-Whitney U-test was applied as a non-parametric test between patient and control groups. All values were given as mean \pm standard deviation. The confidence interval was set at $95 \%$, and a $p$ value of $<0.05$ was considered significant.

\section{RESULTS}

We evaluated 25 patients ( 22 males, 3 females), who were admitted to our hospital with acute exacerbation of COPD, as well as 21 healthy control subjects (17 males, 4 females). The demographic characteristics of the study participants are summarized in Table 1. There was no significant difference between the groups in terms of age, gender, and body mass index $(p=0.130, p=0.120$, and $p=0.195$, respectively). The mean age of the patients with COPD was $67.7 \pm 8.8$ years, while the mean age of the control group participants was $64.90 \pm 11.70$ years. A total of $88 \%$ of COPD patients and $80 \%$ of the control subjects were male (Table 1). The distribution of $A B G$ measurements among the patients with acute exacerbation of COPD is shown in Table 2.

Based on the arterial $\mathrm{PaO}_{2}$ hypoxemia levels of COPD patients, the mean AS values were $1498.00 \pm 699.35$ dyne.sec.cm -5 in those with mild hypoxemia (60-80 mm Hg), 2095.09 \pm 883.31 dyne.sec.cm-5 in those with moderate hypoxemia $(40-59 \mathrm{~mm} \mathrm{Hg})$, and $2077.66 \pm 99.15$ dyne.sec.cm-5 in those with severe hypoxemia ( $<40 \mathrm{~mm} \mathrm{Hg}$ ), which was not statistically significant ( $p>0.05)$, as shown in Table 3. There was

Table 1. Demographic characteristics

\begin{tabular}{|l|c|c|c|}
\hline Gender (Male/Female) & Patient group & Control group & P \\
\hline Age & $22 / 3$ & $17 / 4$ & $0.120^{\mathrm{a}}$ \\
Weight & $67.7 \pm 8.8$ & $64.90 \pm 11.70$ & $0.130^{\mathrm{b}}$ \\
Height & $75.32 \pm 16.55$ & $69.95 \pm 10.62$ & $0.095^{\mathrm{b}}$ \\
BMI & $166.28 \pm 8.48$ & $165.09 \pm 7.58$ & $0.654^{*}$ \\
\hline & $27.40 \pm 5.46$ & $25.20 \pm 5.07$ & $0.195^{*}$ \\
\hline
\end{tabular}

BMI: Body mass index, ${ }^{\mathrm{a}}$ Mann-Whitney U-test, ${ }^{\mathrm{b}} \mathrm{Chi}$-square test. 
Table 2. Distribution of arterial blood gas measurements in acute exacerbation of chronic obstructive pulmonary disease

\begin{tabular}{|l|c|} 
& Mean $\pm \mathrm{SD}$ \\
$\mathrm{pH}$ & $7.3 \pm 0$ \\
$\mathrm{PaCO}_{2}(\mathrm{mmHg})$ & $48.7 \pm 11.4$ \\
$\mathrm{PaO}_{2}(\mathrm{mmHg})$ & $57.3 \pm 12.3$ \\
$\mathrm{SaO}_{2}(\%)$ & $88 \pm 6.8$ \\
$\mathrm{pH}:$ Blood acid- base constant; $\mathrm{PaCO}_{2}$ : arterial blood partial carbon dioxide pressure; \\
$\begin{array}{l}\mathrm{PaO}: \text { arterial blood partial oxygen pressure; } \mathrm{SaO}_{2}: \text { blood oxygen saturation percent- } \\
\text { age; SD: standard deviation }\end{array}$ \\
\hline
\end{tabular}

a statistically significant difference in values of arterial stiffness, compared between mild hypoxemia $\left(\mathrm{PaO}_{2} \geq 60 \mathrm{~mm} \mathrm{Hg} ; 1498.00 \pm 699.35\right.$ dyne.sec.cm-5) and moderate and severe hypoxemia $\left(\mathrm{PaO}_{2}<60 \mathrm{~mm}\right.$ Hg; mean 2086.375 \pm 491.23 dyne.sec.cm-5) $(p=0.047)$ (Table 3).

The LAEI $(9.84 \pm 2.82 ; 12.45 \pm 2.79 \mathrm{~mL} / \mathrm{mm} \mathrm{Hgx} 10)$ and SAEI (4.15 \pm 3.68 ; $6.00 \pm 3.45 \mathrm{~mL} / \mathrm{mm} \mathrm{Hgx100)}$ values were significantly lower in the patient group as compared to the control group $(p=0.043$ and $p=0.036$, respectively). AS was significantly higher in the patient group compared to the control group $(1859.17 \pm 509.52 ; 1215.80 \pm 267.12$ dyne. sec.cm-5; $\mathrm{p}=0.002$ ). While not in a statistically significant way, TVI was higher in the patient group $(192.95 \pm 41.28 ; 140.90 \pm 25.69$ dyne.sec. $\mathrm{cm}-5 ; \mathrm{p}=0.197)$, as shown in Table 4.

\section{DISCUSSION}

In our study, patients with acute exacerbation of COPD were found to have significantly higher AS as compared to the control group. The most important result of the present study is the statistically significant values of AS, compared between mild hypoxemia $\left(\mathrm{PaO}_{2} \geq 60 \mathrm{~mm}\right.$ $\mathrm{Hg}$; group 1) and moderate and severe hypoxemia $\left(\mathrm{PaO}_{2}<60 \mathrm{~mm} \mathrm{Hg}\right.$; groups 2,3 ) in acute COPD cases.

Multiple studies have demonstrated the correlation between PWV and the stage of COPD according to Global Initiative for Chronic Obstructive Lung Disease, indicating that more severe airflow limitations are associated with higher PWV values $(6,10,13)$. COPD and hypoxemia increase AS, leading to thickening of arterial walls, atherosclerotic plaque formation, and vascular remodeling. This indicates that AS increases in the later stages of COPD, with the process starting in the early stages and worsening with the decline in pulmonary function (13). Circulating interleukin- 6 and C-reactive protein levels, which increase during acute exacerbation of COPD, play a role in atherosclerotic plaque formation (10). At the same time, AS may reflect pathological mechanisms, such as systemic inflammation, connective tissue abnormalities, impaired endothelial function, or nitric oxide production, which are associated with pathogenesis of COPD (14).

Patients with COPD often develop hypoxia that can be intermittent (e.g., during exacerbation or related to sleep desaturation) or sustained in more severe cases. Acute exposure to hypoxia increases chemoreflex activation of sympathetic outflow in healthy individuals (16). Sympathetic overactivity has been observed in both hypoxemic and normoxic COPD patients $(17,18)$. Heindl et al. $(16)$ showed that muscle sympathetic nerve activity decreased significantly during oxygen administration in hypoxemic patients, while no change was observed in the control subjects.
Table 3. Findings showing the association between arterial stiffness and arterial partial oxygen pressure in patients with acute exacerbation of chronic obstructive pulmonary disease

\begin{tabular}{|l|c|c|c|}
$\begin{array}{l}\text { Hypoxemia degree } \\
\left(\mathrm{PaO}_{2}\right)^{\dagger} \\
(\mathrm{mmHg})\end{array}$ & $\begin{array}{c}\text { Patient } \\
\text { number }\end{array}$ & Min-Max & $\begin{array}{l}\text { Arterial stiffness } \\
\text { (dyne/sn/cm-5) } \\
\text { Mean } \pm \text { SD }\end{array}$ \\
\hline Group 1=60-80 & 11 & $846-2995$ & $1498.00 \pm 699.35$ \\
\hline Group 2=40-59 & 11 & $1223-3382$ & $2095.09 \pm 883.31$ \\
Group 3=<40 & 3 & $1968-2161$ & $2077.66 \pm 99.15$ \\
\hline Total & 25 & $846-3382$ & $1859.17 \pm 788.10$
\end{tabular}

Kruskal-Wallis test (between group 1 and groups 2, 3) $p=0.047$

${ }^{\dagger}$ : Arterial blood partial carbon dioxide pressure; ": Standard deviation

Table 4. Values measured via pulse wave velocity

\begin{tabular}{|l|c|c|c|} 
& Patient group & Control group & $\mathbf{P}$ \\
\hline LAEI & $9.84 \pm 2.82$ & $12.45 \pm 2.79$ & 0.043 \\
SAEI & $4.15 \pm 3.68$ & $6.00 \pm 3.45$ & 0.036 \\
AS & $1859.17 \pm 509.52$ & $1215.80 \pm 267.12$ & 0.002 \\
TVI & $192.95 \pm 41.28$ & $140.90 \pm 25.69$ & 0.197
\end{tabular}

LAEI: Large artery elasticity index $(\mathrm{mL} / \mathrm{mm} \mathrm{Hgx} 10)$; SAEI: small artery elasticity index ( $\mathrm{mL} / \mathrm{mm} \mathrm{Hgx100);} \mathrm{AS:} \mathrm{arterial} \mathrm{stiffness} \mathrm{(} \mathrm{mL} / \mathrm{mm} \mathrm{Hgx100);} \mathrm{TVl:} \mathrm{total} \mathrm{vascular} \mathrm{imped-}$ ance (dyne/sec/cm-5); Mann-Whitney U-test was used.

The increase in AS and decline in pulmonary function observed in COPD is thought to be linked to an increase in connective tissue destruction (19), which may be related to congenital changes in extracellular matrix synthesis, destruction, and/or repair (5). Elastin is a protein that acts in vessel smooth muscle cell organization and plays a role in the increase in AS (20). Degradation of elastin in AS and elastin loss in emphysema both lead to alveolar septal thickening. Further, elastolytic activity (matrix metalloproteinase-9 and -12) increases in both emphysema and AS and leads to elastin destruction (5). The destruction of the pulmonary elastin structure leads to loss of alveolar structure and a decline in compliance, and eventually, emphysema occurs in the lung (21). In old age, destruction of elastin structure and increase in collagen tissue cause the arteries to become larger and thicker, increasing AS (22). McAllister et al. (6) state that pulmonary stiffness and AS have similar pathophysiological mechanisms and point to a correlation between severity of COPD and AS that is independent of smoking. Another mechanism that indicates a link between severity of emphysema and AS is hypoxia. In the same study, McAllister et al. (6) demonstrated a correlation between pulse oxygen saturation and AS, with the variables controlled.

Chronic obstructive pulmonary disease patients exhibit other abnormalities in systemic vascular dynamics in addition to higher AS. An increase in large artery stiffness leads to higher central aortic systolic pressure and left ventricular end-systolic volume and a decline in diastolic filling of the coronary artery, which increases cardiovascular risk in COPD patients $(5,23)$. The stiffness of the aorta as a high-flow artery forms via the effects of the extracellular matrix, vascular smooth muscle, and endothelium; the regulation of resistance and blood flow in vessels of the aorta is also managed primarily by vascular smooth muscle and the endothelium (24). Maclay et al. (9) found that arteri- 
al wall stiffness significantly increased while systemic vasomotor and endothelial fibrinolytic function did not deteriorate in male COPD patients as compared to control subjects who were well matched in terms of age and smoking habits. Increase in AS is thought to indicate the mechanical relationship between COPD and the associated increased risk of cardiovascular disease. Sabit et al. (10) found that increased AS is correlated with severity of airflow obstruction and is a risk factor for cardiovascular disease. In our study, we found statistically significant values of $A S$, compared between mild hypoxemia $\left(\mathrm{PaO}_{2} \geq 60 \mathrm{~mm}\right.$ $\mathrm{Hg}$; group 1) and moderate and severe hypoxemia $\left(\mathrm{PaO}_{2}<60 \mathrm{~mm} \mathrm{Hg}\right.$; groups 2,3 ) in patients with acute exacerbation of COPD.

According to Nam et al. (24), when the average AS measured from the brachial artery is 1426 dyne.sec.cm-5 and above, the sensitivity for detecting severe coronary artery stenosis is $77 \%$, while specificity is $63 \%$. A similar study by Kim et al. (25) showed that an average AS value of 1635 dyne.sec.cm-5 and above was closely correlated with the Gensini score and multiple occlusive coronary artery disease. In slight discordance with the studies above, the average AS value was 1859 dyne.sec.cm-5 in our study. Hung et al. (4) maintain that measuring PWV is crucial in detecting early atherosclerosis and may be used as an indicator of long-term cardiovascular disease risk.

LAEI and SAEl, which we used in our study, are only two of the parameters that are used as a measure of AS. LAEI and SAEl are indirect hemodynamic markers of endothelial function disorders, and their importance has been demonstrated in previous studies. Duprez et al. (26) showed that the inverse association between SAEI and carotid intima-media thickness was an indirect marker of endothelial function disorder. Grey et al. (27) reported a negative correlation between SAEl and risk of cardiovascular events over a 7-year follow-up period. In our study, the AS value was significantly higher $(1859.17 \pm 509.52$ and $1215.80 \pm 267.12$ dyne.sec.cm-5, respectively; $\mathrm{p}=0.002$ ), while LAEI and SAEI were lower in patients with acute exacerbation of COPD as compared to the healthy control subjects, in accordance with previous studies.

\section{CONCLUSION}

In $\mathrm{PaO}_{2}<60 \mathrm{~mm} \mathrm{Hg}$, AS values were higher than in $\mathrm{PaO}_{2} \geq 60 \mathrm{~mm} \mathrm{Hg}$ during acute exacerbation of COPD. LAEI and SAEI were lower, while AS was higher in COPD patients as compared to healthy individuals. These findings indicate that pulse wave velocity, a practical and noninvasive method of measuring AS, may be effective in predicting cardiovascular events in COPD patients.

\section{Study Limitation}

The number of patients with severe hypoxemia and total number of patients were small. This was a cross-sectional study.

Etik Komite Onayı: Bu çalışma için etik komite onayı Uludağ Üniversitesi Etik Kurulu'ndan alınmıştır.

Hasta Onamı: Yazılı hasta onamı bu çalışmaya katılan hastalardan alınmıştır. Hakem Değerlendirmesi: Dış bağımsız.

Yazar Katkıları: Fikir - S.Ö., O.A.S., E.U.; Tasarım - S.Ö., I.Ö.; Denetleme - S.Ö., O.A.S., E.U.; Kaynaklar - S.Ö., I.Ö.; Malzemeler - S.Ö., I.Ö.; Veri toplanması ve/ veya işlemesi - S.Ö., I.Ö.; Analiz ve/veya yorum - S.Ö., I.Ö.; Literatür taraması S.Ö., I.Ö.; Yazıyı yazan - S.Ö., I.Ö.; Eleştirel inceleme - O.A.S., E.U.

Teşekkür: Hastanemiz biyoistatistik birimine desteklerinden dolayı teşekkür ederiz.

Çıkar Çatışması: Yazarlar çıkar çatışması bildirmemişlerdir.
Finansal Destek: Yazarlar bu çalışma için finansal destek almadıklarını beyan etmişlerdir.

\section{REFERENCES}

1. Celli BR, MacNee W. ATS/ERS Task Force. Standards for the diagnosis and treatment of patients with COPD: a summary of the ATS/ERS position paper. Eur Respir J 2004; 23: 932-46. [CrossRef]

2. Gross NJ. Extrapulmonary effects of chronic obstructive pulmonary disease. Curr Opin Pulm Med 2001; 7: 84-92. [CrossRef]

3. Agustí AGN, Noguera A, Sauleda J, Sala E, Pons J, Busquets X. Systemic effects of chronic obstructive pulmonary disease Eur Respir J 2003; 21 : 347-60. [CrossRef]

4. Hung CS, Lin JW, Hsu CN, Chen HM, Tsai RY, Chien YF, et al. Using brachial-ankle pulse wave velocity to associate arterial stiffness with cardiovascular risks. Nutr Metab Cardiovasc Dis 2009; 19: 241-6. [CrossRef]

5. Sin DD, Man SF. Chronic obstructive pulmonary disease as a risk factor for cardiovascular morbidity and mortality. Proc Am Thorac Soc 2005; 2: 8-11. [CrossRef]

6. McAllister DA, Maclay JD, Mills NL, Mair G, Miller J, Anderson D, et al. Arterial stiffness is independently associated with emphysema severity in patients with chronic obstructive pulmonary disease. Am J Respir Crit Care Med 2007; 176: 1208-14. [CrossRef]

7. Shen L, Wu W, You B, Gao H, Wang C, Liu Y. Relationship between pulse wave velocity and carotid atherosclerosis in geriatric people. Cerebrovasc Dis 2011; 32: 16-20. [CrossRef]

8. Song HG, Kim EJ, Seo HS, Kim SH, Park CG, Han SW, et al. Relative contributions of different cardiovascular risk factors to significant arterial stiffness. Int J Cardiol 2010; 139: 263-8. [CrossRef]

9. Maclay JD, McAllister DA, Mills NL, Paterson FP, Ludlam CA, Drost EM, et al. Vascular dysfunction in chronic obstructive pulmonary disease. Am J Respir Crit Care Med 2009; 180: 513-20. [CrossRef]

10. Sabit R, Bolton CE, Edwards PH, Pettit RJ, Evans WD, McEniery CM, et al. Arterial stiffness and osteoporosis in chronic obstructive pulmonary disease. Am J Respir Crit Care Med 2007; 175: 1259-65. [CrossRef]

11. Global Initiative for Chronic Obstructive Lung Disease (GOLD): Pocket Guide to COPD Diagnosis, Management and Prevention, (Updated 2013). (http://www.goldcopd.org/uploads/users/files/GOLD_Pocket_2013_Mar27.pdf).

12. Acıcan T. Arterial Blood Gases. Journal of Intensive Care 2003; 3: 160-75.

13. Cinarka H, Kayhan S, Gumus A, Durakoglugil ME, Erdogan T, Ezberci I, et al. Arterial stiffness measured by carotid femoral pulse wave velocity is associated with disease severity in chronic obstructive pulmonary disease. Respir Care 2013; 59: 274-80. [CrossRef]

14. Barr RG, Mesia-Vela S, Austin JH, Basner RC, Keller BM, Reeves AP, et al. Impaired flow mediated dilation is associated with low pulmonary function and emphysema in exsmokers: the Emphysema and Cancer Action Project (EMCAP) Study. Am J Respir Crit Care Med 2007; 176: 1200-7. [CrossRef]

15. Woolam GL, Schnur PL, Wallbona C, Hoff HE. The Pulse Wave as an Early Indicator of Atherosclerosis in Diabetic Subjects. Circulation 1962; 25: 533-9. [CrossRef]

16. Heindl, S, Lehnert M, Criée CP, Hasenfuss G, Andreas S. Marked sympathetic activation in patients with chronic respiratory failure. Am J Respir Crit Care Med 2001; 164: 597-601. [CrossRef]

17. Scalvini S, Porta R, Zanelli E, Volterrani M, Vitacca M, Pagani M, et al. Effects of oxygen on autonomic nervous system dysfunction in patients with COPD. Eur Respir J 1999; 13: 119-24. [CrossRef]

18. Stein PK, Nelson P, Rottman JN, Howard D, Ward SM, Kleiger RE, et al. Heart rate variability reflects severity of COPD in PiZ alpha1-antitrypsin deficiency. Chest 1998; 113: 327-33. [CrossRef]

19. Sin DD, Man SF. Why are patients with chronic obstructive pulmonary disease at increased risk of cardiovascular diseases? The potential role of systemic inflammation in chronic obstructive pulmonary disease. Circulation 2003; 107: 1514-19. [CrossRef]

20. Brooke BS, Bayes-Genis A, Li DY. New insights into elastin and vascular disease. Trends Cardiovasc Med 2003; 13: 176-81. [CrossRef] 
21. Shifren A, MechamRP. The stumbling block in lung repair of emphysema: elastic fiber assembly. Proc Am Thorac Soc 2006; 3: 428-33. [CrossRef]

22. Zieman SJ, Melenovsky V, Kass DA. Mechanisms, pathophysiology, and therapy of arterial stiffness. Arterioscler Thromb Vasc Biol 2005; 25: 932-43. [CrossRef]

23. Safar ME, Levy BI, Struijker-Boudier H. Current perspectives on arterial stiffness and pulse pressure in hypertension and cardiovascular diseases. Circulation 2003; 107: 2864-9. [CrossRef]

24. Nam HJ, Jung IH, Kim J, Kim JH, Suh J, Kim HS, et al. Association between brachial-ankle pulse wave velocity and occult coronary artery disease detected by multi-detector computed tomography. Int J Cardiol 31; 157: 227-32.
25. Kim HJ, Nam JS, Park JS, Cho M, Kim CS, Ahn CW, et al. Usefulness of brachial-ankle pulse wave velocity as a predictive marker of multiple coronary artery occlusive disease in Korean type 2 diabetes patients. Diabetes Res Clin Pract 2009; 85: 30-34. [CrossRef]

26. Duprez DA, De Buyzere ML, De Backer TL, Clement DL, Cohn JN. Relationship between arterial elasticity indices and carotid arterial elasticity intima-media thickness. Am J Hypertens 2000; 13: 1226-32. [CrossRef]

27. Grey E, Brattel C, Glasser SP, Alinder C, Finkelstein SM, Lindgren BR, et al. Reduced small artery but not large artery elasticity is an independent risk marker for cardiovascular events. Am J Hypertens 2003; 16: 265-9. [CrossRef] 